\title{
Pastoralism and Development Policy in Ethiopia: A Review Study
}

\author{
Abduselam Abdulahi Mohamed \\ Department of Agricultural Economics and Agribusiness Management, Kebri Dehar University, Kebridahar, \\ Ethiopia \\ Abdisalan654@gmail.com
}

\begin{abstract}
Pastoralism is a culture, livelihoods system, extensive use of rangelands. It is the key production system practiced in the arid and semi-arid dryland areas. Recent estimates indicate that about 120 million pastoralists and agro-pastoralists life worldwide, of which 41.7\% reside only in sub-Saharan Africa (SSA). Pastoralists live in areas often described as marginal, remote, conflict prone, food insecure and associated with high levels of vulnerability. Pastoral communities of Ethiopia occupy $61 \%$ of the total land mass and 97\% of Ethiopian pastoralists found in low land areas of Afar, Somali, Oromiya, and SNNPR. In spite pastoral areas have significance role in national economy, yet very little consideration was given to pastoral development and policy makers often neglect them, focusing on the interests of agriculture and urban people. The constitution of Ethiopia gives pastoral communities the right to free land grazing, fair use of natural resources, have market access and receive fair price, and not displaced from their own lands. However, pastoralists have faced new problems in recent years, including competition for water and pasture; unrepresented in socio-economic and political activities, ethnic based conflicts, poverty, and uneven drought and climate changes. The government of Ethiopia began large scale efforts to develop the pastoral areas and initiated different projects, but pastoral development policies and strategies seem to be state centrally-driven. In Ethiopia the current nature of pastoralism and pastoral communities' life style is changing. Therefore, government needs to develop policies and strategies which are based on local customs and practical knowledge.
\end{abstract}

Keywords: Pastoralism; pastoralist; policy; strategy; marginal; Ethiopia.

\section{Introduction}

Pastoralism is not only the way of life for pastoralists, but also a culture, symbol of love and integrate, economic and livelihood system, one of the basic pastoral risk management strategies and rational use of drylands. It is life system mostly found in Africa's vast arid and semi-arid areas which are manifested by rainfall variability, and associated uncertainties in the spatial and temporal distribution of water resources and grazing for animals. Pastoralism is practiced mainly on the grasslands that cover about a quarter of the world's surface (Follet \& Reed, 2010). It is closely associated with mobile herds and with the drylands (Robinson et al., 2011). Pastoralists use mobility as a basic strategy for their livelihood development and risk management systems. Although African pastoral ecosystems are ancestral homeland to a substantial portion of the population for whom pastoralism is a traditional way of life, pastoralism is far from static. Pastoralists in many areas are adapting to trends such as new economic opportunities and better access to modern means of communication (AU/DREA, 2010).

The understanding of pastoralism has changed continuously in the last decades. It has shifted from the view of pastoralism as an irrational way of life towards a systemic territorial approach. This happen, because of nowadays sustainability and resilience is taking an increasing role in the international development debate. Pastoralism is a key characteristic of the people in the Horn of Africa. It was estimated that approximately 20 million pastoralists live in the region in which they create significant migration flows; they move seasonally, often 
crossing porous borders in search of water, grazing lands, better livelihoods or simply safer environments (Ginetti \& Franck, 2014; Anand, 2014). Pastoralists adapted to ecosystems defined as marginal, underdeveloped, characterized by lack of peace and stability, poor infrastructure, variable and unpredictable agro-ecological resource endowment, and unrepresented in socio-economic and political activities.

Pastoralism supports several hundred million households worldwide. Accounting for 50 million households only in sub-Saharan Africa, yet policy makers often neglect them (Pastoralist Knowledge Hub, 2016 \& Swallow, 1994), and the nature of pastoralism is changing. In the face of demographic trends, prolonged conflicts, reduced access to grazing land and water, erratic drought and climate change, food insecurity, and the impacts of livestock diseases are worsening. These trends coincide with the limited political representation of pastoralists in the decision-making processes affecting their livelihoods, which in turn, is exacerbated by their physical position in remote areas, far from political and economic centers. Many researchers and scholars believe that suffering of pastoralists hardships are self-inflicted due to their apparent choice for a traditional life style that inhibits their ability for innovations and adaptation to recent global change, which is not true and misconception of believe. Pastoralists do not suffer due to their choice for traditional life style, but suffer due lack of inclusive government development policies.

Pastoralists have multiple political identities: pastoral, livestock-keeping, regional, ethnic, religious, and "indigenous peoples" (Andreas et al., 2017). In general speaking, Pastoralists live in marginalized, remote and underdeveloped areas. In the pastoral areas illiteracy rate is very high and majority of their children not in school (UNICEF, 2014). Pastoral communities not have educational access. However, the morality of the parents is very emphasized by teachings their children Islamic studies (Quran) (Suheri et al., 2019). Pastoralists are often described as conflict prone, food insecure and associated with high levels of vulnerability. Basic social services like health, education, electricity, road and communication, accessibility of agricultural extension service, access to credit and insurance service are usually less-well developed than in other areas, therefore pastoral areas are defined as the area with low health and education indicators than national-level figures at any time.

\section{Literature Review}

\subsection{Definition and Concept of Pastoralism}

The worldwide literature on pastoralism is extremely uneven and determined by socioeconomic, culture and political issues related with pastoral communities, as well as by the need of empirical data availability. Based on limited available knowledge of pastoralism, different Organizations and Scholars are defined pastoralism in different ways. FAO defined as "extensive livestock production in the pastures". The United Nation Convention No. 169(1989) defined as "ethnic identity, Indigenous and Tribal Peoples".

Pastoralism scientifically defined as "A member of social groups with a strong traditional association with livestock keeping, where a substantially proportion of the group derive over $50 \%$ of the household consumption from livestock products or their sales, and where over $90 \%$ of animal consumption is from natural pasture, and where members of the households are responsible for the full cycle of the livestock breeding”. Definition of pastoralism in Ethiopian context related with mobility, but this may not be the true in the world 
context where large herds of livestock sometimes managed by sedentary households by just allowing them to roam freely during the dry season. People move away from drought, animal disease or conflict, towards newly available resources, this is why mobile cannot fully define pastoralism. Pastoralism may be thought as a system in a range of livestock and non-livestock activities connect through a web of social and economic relationships that extend well beyond lowland areas to highland economies and across the nation's borders (Lind, Sabates-Wheeler \& Kohnstamm, 2016).

Pastoralism, the use of extensive grazing in rangelands for livestock production, is one of the key production, economic, and livelihood systems in the world's drylands. Nonetheless, throughout much of its long history its reputation has been unflattering, its practitioners marginalized by sedentary cultivators and urban dwellers. Pastoral societies have risen and fallen, fragmented into isolated families or constructed world-spanning empires and their demise regularly announced, often in the face of entirely contrary evidence of their persistence (Roger Blench, 2001).

According to Roger (2001), pastoralism never developed because population pressure on land remained limited, it strongly associated with the presence of grasslands, but can be found numerous grasslands without pastoralists. But, I strongly disagree with this researcher because pastoralism can be developed and disappeared with the change of land use policy of the nation. In most parts of the world, except Africa, agriculture seems to be earlier than pastoralism and pastoralism was developed later. Pastoralism existence has had complex relationships with hunter-gatherers history of the human being, green revolution and the nature of land ownership in many parts of the world. Melville (1994), suggested that pastoralism was developed in North and Central America post the Spanish era as Amerindian peoples gained access to European ruminants or migrants from the Old World settled and began to farm in that area which have been adopted in very contrastive fashions, then these peoples were termed as "true pastoralism".

The foundation of pastoralism has been much discussed, especially by older type of literature. Pastoralism lifestyle developed from surplus and pastoralists' experience, as individuals accumulate too many animals to graze them around a settlement throughout the year pastoralism was developed. Similarly, as herders learnt more about the relations between particular types of ecology and the spread of livestock diseases they gradually practice of seasonal migration by their animals from danger areas.

\subsection{Ethiopian Pastoralism and Policy Concern}

Policies of post-colonial governments have led to the marginalization of pastoralists from mainstream national development in most countries in the Horn of Africa. Over the years, there has been a tendency to neglect the needs of pastoralists and even to envisage the gradual eradication of pastoralism since most of the governments' policies focus on the interests of agriculture and urban dwellers, thus marginalizing pastoral communities. The different narratives affect the decisions and policies made by government and development organizations. But these are often poorly suited to the situation faced by pastoralists, service providers and other organizations in the drylands. A better understanding of pastoralism is needed to improve decision-making that affects pastoral areas and the people who live there (Andreas et al., 2017).

Pastoralists in Ethiopia are mainly found in four lowland regions, Afar, Somali, Oromiya, and the Southern Nations, Nationalities and People's (SNNP) regional states. Pastoral groups 
are also found in Gambella and Benishangul areas. The main livelihoods systems include pastoralism, farming and ex-pastoralism - those who have dropped out of pastoralism and now survive on petty income-earning activities (Behnke et al., 2007).

Pastoralist communities in Ethiopia occupy the largest percentage of the country's total land area along the borders of Somalia, Kenya and Sudan. In deed this extends to the border of Djibouti as well. Pastoral communities of Ethiopia occupy 61 percent of the total land mass with more than 29 nationalities and ethnic groups, which comprise Arid and Semi-Arid climatic conditions. The pastoralists are traditionally nomadic ethnic groups that are highly mobile, move from one area to another in search of pasture and water for their livestock, well adapted to harsh terrain and extreme climates. Ethiopian pastoralists are freely move from one region to another and not restricted to one area or even country, sometimes they move out of neighboring countries.

Pastoralists are found distributed over 122 districts of the country. More than half of the country's landmass belongs to pastoralists. Besides the mainly known pastoral regions, others like the Gambella and Benishangul-Gumuz regional states have pastoral communities although these regions at the western end of the country have predominantly a shifting cultivation agricultural system. Over $97 \%$ of the pastoral population lives in Somali, Oromia, Afar and Southern Region States (UNDP, 2010). The Ethiopian constitution incorporated the issues of pastoralists by forming separated department for pastoralist issues under the ministry of federal affairs which coordinates and facilitates development in pastoral areas and set up Ethiopian Parliament Pastoralist Affairs Standing Committee (EPPASC) which oversees pastoral development activities in the country. Livestock and Pastoral Development offices have been established in regions where pastoralism is an important production and livelihood system.

The 1995 Ethiopian Constitution states that: pastoralists have the right to free land grazing, fair use of natural resources, to have market access and receive fair prices, and not to be displaced from their own lands without their wish. The government set a national policy and strategies to direct development efforts in the pastoral areas of Ethiopia (Mohammed, 2015). But, these nationally developed policies conflict with each other. For example, Proclamation 819/2014 promotes livestock trade and marketing as a major revenue earner for the country; the policy on voluntary settlement, on the other hand, discourages pastoralist practices in Ethiopia. The mandate of livestock policies is still in confusion to which Ministry it belongs; Ministry of Livestock and Fisheries, Ministry of Agriculture, or the Ministry of Federal Affairs.

Pastoralism policies have been tacitly influenced by unfavorable attitudes (Farvar, 2003; Cited in Boku, 2008). Earlier, Scholars and policy makers believe that Pastoralists are agents of environmental degradation and desertification, and these groups of people are geographically and socially marginalized due to their isolation, inhabiting large areas unsuitable for agriculture and infrastructural development. Such dominant views influenced pastoral policies in the country. Policy makers quietly accepted such assumptions and used them to justify policies for land tenure reform, land privatization, the registration of title deeds, formal land use planning, and livestock controls (Lane, 1998). Such policies determined extensive grazing of pastoralist communities and represent the foundation of unrespect for pastoralism, and became source of conflict among pastoralists and agriculture societies. The options of replacing mobile pastoralism with non-pastoral activities such as cropping and resettlement which were suggested by development programs and policy makers, have failed to work (Anderson and Broch-Due, 1999; Hogg, 1986). 
The contribution of pastoralists to the national economies are often marginalized and ignored. While pastoralism is a risky livelihood, it is still a viable way to use certain areas. This is especially true in regard to climate change, shifting global markets, population growth and increasing competition for land and other natural resources. Understanding how it works is vital for efforts to reduce poverty in pastoral communities (Andreas et al, 2017).

The degree of social and political support for pastoralism is diverse, with some governments strongly opposed, while others (such as in Europe) beginning to support it so as to manage and conserve biological diversity (Nori \& Gemini 2011; Cited in Andreas et al, 2017). The development challenges of pastoral areas are multi-dimensional and complex. Therefore, pastoralism needs inclusive policy for development in every country. Pastoralist communities facing extreme and worsening levels of food insecurity, highly affected by violent conflict, politically and economically marginalized, have decreasing access to the natural resources on which their livelihoods depend, and very limited access to basic socio-economic services and infrastructure. Pastoralists are underdeveloped and poor because of inappropriate development policies which lead to ineffective institutional settings, unfair resource distribution and increased pressure on pastoral ecosystems. Pastoralism in Ethiopia is undergoing profound change (Lind et al, 2016; Rettberg, Beckmann, Minah \& Schelchen, 2017). The nature of pastoralism and their land use is changing now days. Therefore, pastoral development policies should be based on local customs and community practical knowledge rather than imposing state centrally-driven policies.

In spite very little consideration was given to the economic significance of pastoral areas and pastoralist until the mid-1960s. However, after the formation of the Livestock and Meat Board (LMB) in 1964 the government of Ethiopia began large scale efforts to develop the pastoral areas and initiated different pastoral development projects, including among others Arero Range Pilot Project, Livestock Development Project (I, II, III), Southern Rangelands Pilot Project, and Pastoral Community Development Project (PCDP). Pastoralists have faced new problems in recent years, including competition for water and pasture in the context of decreased access to land; more explicit socio-economic and political marginalization, ethnic based conflicts and deteriorating security situation; and uneven drought occurrences in pastoral areas of the country.

Table 1. The Location and Size of Pastoral Areas in Ethiopia

\begin{tabular}{|l|l|l|}
\hline Region & \multicolumn{1}{|c|}{$\begin{array}{c}\text { Total Surface area } \\
\left(\mathbf{6} \mathbf{0 0 0} \mathbf{~ k m}^{2}\right)\end{array}$} & \multicolumn{1}{c|}{$\begin{array}{c}\text { Total Pastoral area } \\
\left(\mathbf{k m}^{2} \mathbf{~ s q .}\right)\end{array}$} \\
\hline Afar & 98.4 & 98.4 \\
\hline Somali & 325.1 & 325.1 \\
\hline Oromia & 353.0 & 152.1 \\
\hline Gambella & 25.8 & 17.3 \\
\hline Benishangul-Gumuz & 48.3 & 8.4 \\
\hline SNNP & 112.3 & 30.4 \\
\hline Dire Dawa & 1.2 & 1.2 \\
\hline Total & $\mathbf{9 5 6 . 1}$ & $\mathbf{6 2 4 . 8}$ \\
\hline
\end{tabular}

Source: (EEA, 2005; Cited in UNDP, 2010). 


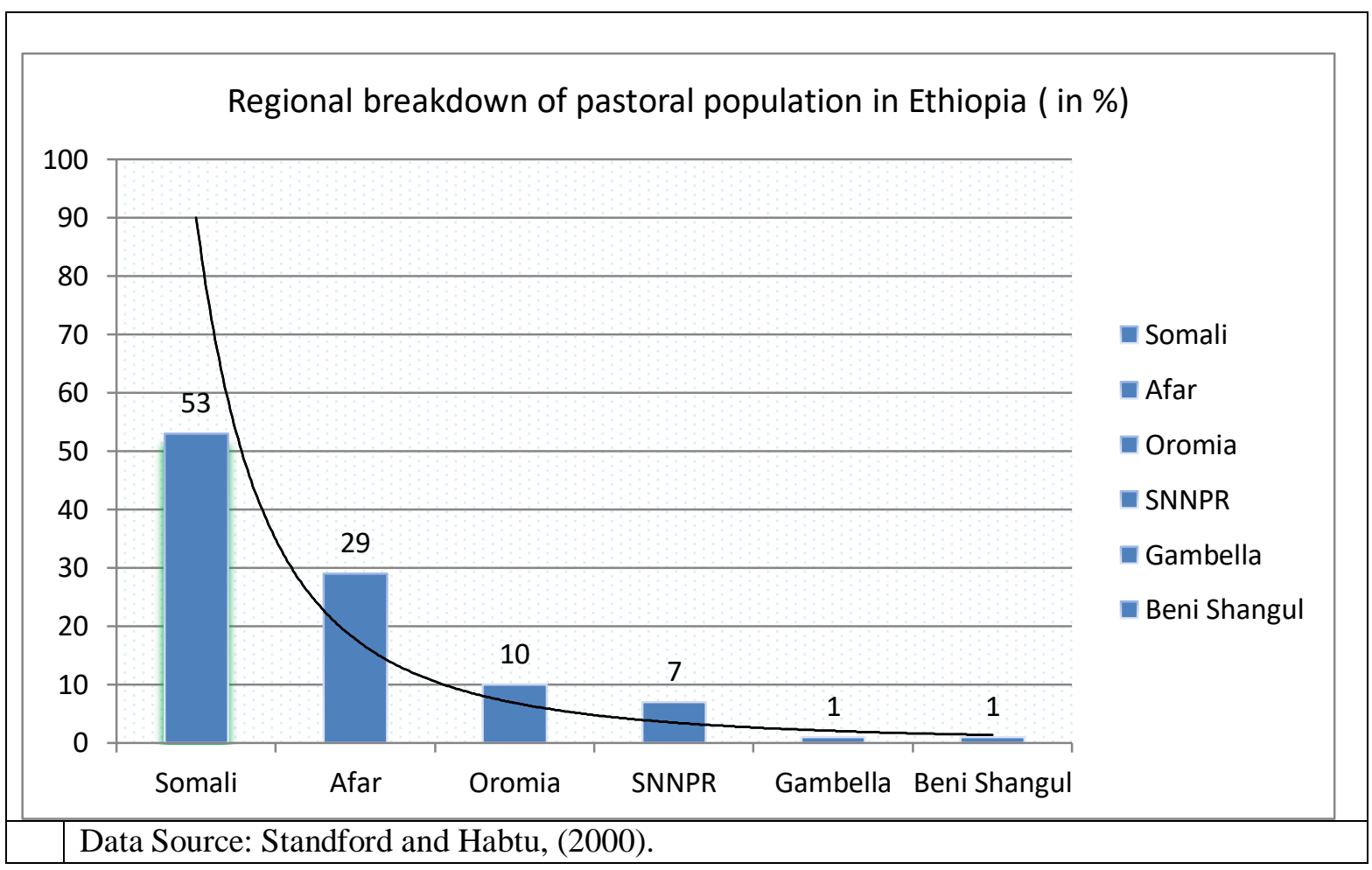

Figure 1. Pastoral population distribution in Ethiopia

\section{Discussion}

\subsection{Somali, Afar and Borana Pastoralists}

Pastoralism in Ethiopia is poorly documented by far, with confused description of pastoral systems and terminology used for pastoralist groups. In Ethiopia pastoralists are usually tribally organized referred to as Somali pastoral, Afar pastoral and Borana-Oromo pastoral and associated with particular territories inhabited exclusively by them. Pastoralists are also found in areas of Tigray, Benishangul and Gambella. According to Coppock (1994), the Somali pastoralists constitute 53 percent of the pastoral population followed by the Afar 29 percent, the Borana-Guji Oromia 10 percent and the remaining 8 percent are found in Gambella, Benishangul and Tigray regions.

Somali Pastoralists: Somali pastoralists move between seasonal grazing areas, taking strategic advantage of different forage and water sources as they become available. In Somali region 60 percent of the population was still practicing pastoralism as a main livelihood activity (Save the Children UK (2008) cited in Lind et al, (2016). According to Mohamed (2018), the nature of the land ownership and acquisition for Somali pastoralists changing this is associated with changing the nature of the land use since state land is interested nowadays in Somali region following resettlement. State land is a recent phenomenon defined as covering work, face, making roads, building, plant, and other infrastructural development supports (Ismail Mahli, 2019). Accessibility of land to pastoralists decline in Somali region since pasture and water started to fall under the private control of other Somalis. Somali pastoralists are well known by their movement to find pasture and water for their livestock. These movements are one of the major sources of misunderstanding and conflict between them and their neighbors. 
In Somali region, land is owned by sub-clans, and whether someone can claim land or not depends on the decision of the sub-clan. According to (Alison N. \& Solomon D., 2011), the situation of pastoralists' area closure and land uses varies by location. In some parts of the region much land has already been privatized and enclosed. Unlike parts of Somali region including Shinille and Korahey zones, there are still large areas of open common grazing land.

Afar Pastoralists: The traditional Afar pastoralist system involves transhumant migration between dry and wet season pastures. Similar to other pastoral communities in Ethiopia, the major challenges of Afar pastoralist are recurrent drought and climate change. But, Afar pastoralists do not see water as the main problem which makes them move, since they are near to Awash River (Guinand Y., 2000). It is rather the circumstance and the fact that drought periods exhaust grazing areas animals have to move ever-longer distances for fodder. Afar pastoralists are very similar to Somali pastoralists in terms of their mobility and livelihoods, but with less involvement in livestock exports. However, during the last decades, Afar pastoralists became characterised by substantial losses of communal grazing areas along the Awash River, due to dams for hydroelectric power, and large-scale irrigated cotton and sugar schemes (Kloss H., 1982; Rettberg S., 2010). Different from other pastoral areas of the country, decline in land access in Afar region was mainly due to external appropriation of land, supported by central government.

Borana-Oromo Pastoralist: The Borana Plateau is an important rangeland for Ethiopia. Pastoralism mode of production has supported the life of people here for many Centuries, and animals are now supplied to a variety of domestic and export markets. Traditionally, Boran systems of social solidarity provided clans with crucial resiliencies in relation to the sharing of natural resources, livestock holdings, essential daily needs, and conflict. Unlike to other pastoralists in Ethiopia, the leaders of the Borana pastoralists redistributed cattle to those determined to be legitimately in need through no fault of their own. The Borana pastoral system has endured several decades of decline due to several reasons, including climate change, population growth, rangelands degradation, food insecurity and drop in livestock productivity (Coppock et al., 2014). Some of the Borana pastoralists have sought to turn to agriculture, but success in dryland agriculture is equally contingent on reliable rainfall (Stark J. et al., 2011). Borana plateau is an area known by scarce water resource. But, social structure provides a framework within which scarce resources (water and pasture) management is carried out by well-organized traditional administrative structure-GADA.

\subsection{Pastoralism and Vulnerability}

The concept and definition of the pastoralism vulnerability that has been used by different studies revolves around the explaining of vulnerability as lack of adaptive capacity in both social and natural system: sensitivity and exposure to hazard (Adger and Kelly, 1999; Deressa, 2010; Acheampong et al., 2014). Pastoral communities are vulnerable to sudden or gradual changes in social or ecological shocks and stresses. Pastoralism in Ethiopia is both viable and vulnerable. The current climate change, food insecurity and internal conflict crisis are affecting pastoralists' livelihood in the country.

In order to define vulnerability we need to define risk first. Dercon (2001), risk are defined uncertain events that can damage human and livestock wellbeing. The uncertainty pertains to the occurrence, timing and magnitude of the negative event. Based on risk definition vulnerability denotes lack of resilience to the occurrences of these uncertain events, including long-term and seasonal trends. The climatic shock of the drought is one of many sources of 
vulnerabilities for Ethiopian pastoralists. Livestock terms of trade for cereals and other staple commodities have collapsed, while pasture and water resource conflicts have increased. Loss of access to water, pasture and effective, community-based animal health care, all these vulnerabilities led to increases in malnutrition, morbidity and malnutrition (Lautze et al., 2003).

It is not drought as such that makes pastoralists vulnerable, but the growing inability of pastoralists to cope with it. Factors that constrain pastoral drought response mechanisms, especially the mobility of people and animals, are the main reason for this. These factors include restrictions on trade and movement, poverty and poor investment in social services and infrastructure, public policy constraints combine to impoverish pastoralists (ECHO, 2009). Facing food insecurity caused by drought, many pastoralists sell their livestock on the market. Increasing numbers of livestock, often in poor condition, drive down prices. Rich pastoralist entrepreneurs are able to take advantage of this situation. Indeed, pastoralist areas can export increasing numbers of livestock while also seeing increasing levels of destitution (Stark J. et al., 2011). Climate change, drought, food insecurity, conflict and unsafe security issues are key challenges and long-term structural problems for pastoralists in Ethiopia.

Poverty is one of the most development challenges in Africa, as well as Ethiopia. Despite widespread attention was given to poverty alleviation, confusion still exists over the very complex poverty dynamics in pastoral areas. Because pastoralists are often poor as results of low standard indicators like cash expenditures, education and market access (Devereux, 2007). According to (Peter et al., 2008) reliance on quantitative measurements are highly questionable in the context of pastoralism and a seeming unwillingness to fully value pastoral production and consumption leads to misperceptions about the nature and extent of poverty among pastoral populations.

Pastoralism in everywhere uniquely well adapted to dryland environments. As an economic and social system, it operates effectively in low and highly variable rainfall conditions. Ethiopian pastoralists' livelihoods systems are becoming increasingly vulnerable due to rising human populations, climate change, completion for scarce resources; very poor infrastructure development and international markets are setting ever-higher barriers for access (Sara Pantuliano and Mike Wekesa, 2008).

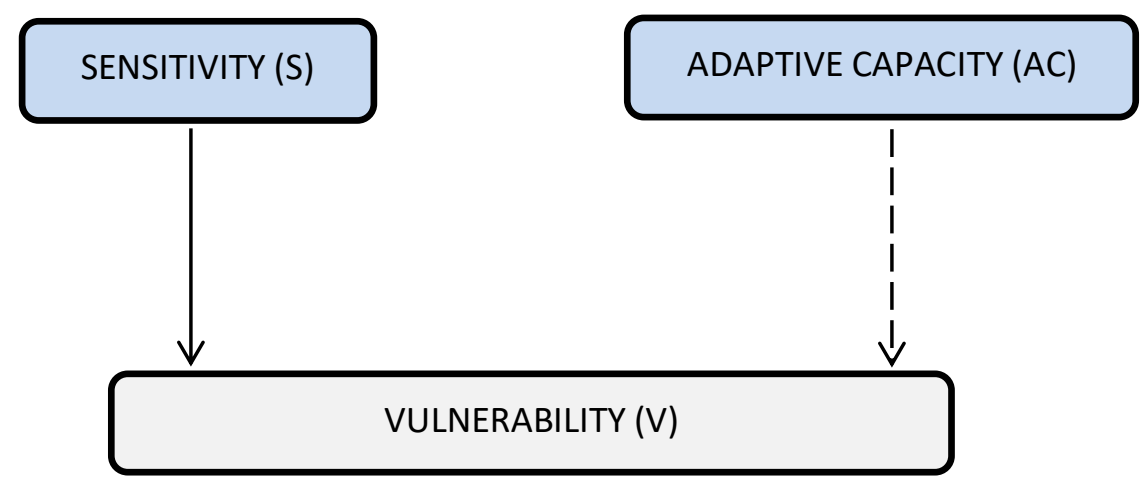

Figure 2. Vulnerability Conceptual framework, taken from IPCC (2014). Solid and dashed arrows show positive and negative functional relationship of component with vulnerability, respectively. 
According to the Intergovernmental Panel on Climate Change (IPCC), Working Group II Report (2014). Vulnerability presented as pre-existing characteristic property of a system. Accordingly, indicators 'Sensitivity' and 'Adaptive capacity' are internal properties of a system, are employed to assess vulnerability.

\section{Conclusion}

Pastoralism is a culture, way of life, economic and livelihood system. Pastoralist livelihoods have come under increasing strain as a result of external shocks, both natural and man-made. As a result of drought, changing public policies and strategies towards pastoral communities, continuing loss of pasturelands, population dynamics, and accelerating climate change, violent conflict and displacement, the future of pastoralism and the role that it will play in national economy and sustainable development remains unclear. Policy-makers face a challenging task when designing pastoral development policies and strategies. In fact, many aspects of pastoralism and pastoral communities are still not fully understood and require applied research.

\section{References}

Mohamed, A., A. (2018). Assessment of Conflict Dynamics in Somali National Regional State of Ethiopia. Journal of Public Policy and Administration. 40-48.

Acheampong, E.N., Ozor, N. and Owusu, E.S. (2014). Vulnerability assessment of Northern Ghanato climate variability. Climate Change,126:3144

Adger, W.N. (1999). Social vulnerability to climate change and extremes in Coastal Vietnam. World Development. 249-269.

African Union, Department of Rural Economy and Agriculture (2010). Policy Framework for Pastoralism In Africa: Securing, Protecting and Improving the Lives, Livelihoods and Rights of Pastoralist Communities. www.africa-union.org

Alison, N., and Solomon, D. (2011). "A Review of Pastoral Rangeland Enclosure in Ethiopia. Pastoral Livelihood Initiative (PLI) project, Addis Ababa, Ethiopia.

Anand, S. (2014). Overview of mobile populations in the Horn of Africa. Nairobi, Kenya: Unicef Esaro.

Anderson, D. M., Broch-Due, V., (1999). "Preface," in D. Anderson and V. BrochDue (Eds.), The poor are not us: Poverty and pastoralism. Oxford: James Currey.

Andreas Jenet, Nicoletta Buono, Sara Di Lello, Margherita Gomarasca, Cornelia Heine, Stefano Mason, Michele Nori, Rita Saavedra, Koen Van Troos. (2017). The path to greener pastures: Pastoralism, The Backbone of The World's Drylands. VSF International, in collaboration with AVSF, VSF Belgium, VSF Germany.

Behnke, R., S. Devereux, R. White, M. Wekesa and A. Teshome (2007). The Productive Safety Net Programme in Pastoral Areas: Pilot Design. Addis Ababa.

Boku Tache (2008). Pastoralism under Stress: Resources, Institutions and Poverty among the Borana Oromo in Southern Ethiopia. PhD Dissertation, Department of International Environment and Development Studies, Norwegian University of Life Sciences. 
Coppock, D., L. (1994). The Borana Plateau of Southern Ethiopia: Synthesis of Pastoral Research, Development, and Change, 1980- 1991. System Study No. 5. International Livestock Center for Africa, Addis Ababa, Ethiopia.

D. Layne Coppock, Seyoum Tezera, Bedasa Eba, Jaldessa Doyo, Demisachew Tadele, Derege Teshome, Nizam Husein, and Meiso Guru (2014). Sustainable Pastoralism in Ethiopia: Preliminary Results from Participatory Community Assessments on the North-central Borana Plateau. http://digitalcommons.usu.edu/envs_facpub

Deressa, T.T. (2010). Assessment of the vulnerability of Ethiopian agriculture to climate chan ge and farmers' adaptation strategies. A PhD thesis submitted to the Department of Agr icultural Economics, Extension and Rural Development, University of Pretori.

Derson S., (2001). Assessing Vulnerability to poverty. Jesus College CSAE, Department of Economics, Oxford University.

Devereux, S. (2007). Cashing in or Cashing out: Pastoralist Livelihoods in Somali Region, Ethiopia'. Paper prepared for the 'Living on the Margins' conference, Stellenbosch, South Africa (26-28 March 2007).

Ethiopian Economic Association (2004/05). Transformation of the Ethiopian Agriculture: Potentials, Constraints and Suggested Intervention Measures. REPORT ON THE ETHIOPIAN ECONOMY. Volume IV 2004/05. Addis Ababa.

European Commission under ECHO, (2009). Understanding livelihoods to reduce the vulnerability of pastoral communities. Overseas Development Institute, 111 Westminster Bridge Road London, SE1 7JD, United Kingdom. www.odi.org.uk/hpg

Farvar, T. (2003). 'Myths, challenges and questions on mobile pastoralism in West Asia'. Policy Matters, 12:31-41.

Follet, R.F., and D.A. Reed (2010). Soil carbon sequestration in grazing lands: Societal benefits and policy implications. Rangeland Ecology \& Management 63:1, 4-15

Ginetti, J., \& Franck, T. (2014). Assessing drought displacement risk for Kenyan, Ethiopian and Somali pastoralists. Technical paper. Geneva, Switzerland: Norwegian Refugee Council (NRC) and Internal Displacement Monitoring Centre (IDMC.

Guinand Yves (2000). Afar Pastoralists Face Consequences of Poor Rains Rapid Assessment Mission: UN-Emergencies Unit for Ethiopia.

Hogg, R., (1986). "The new pastoralism: poverty and dependency in northern Kenya," Africa, 319-33.

IPCC (2014). Summary of policymakers In: Climate change 2014: Impacts, Adaptation, and Vulnerability. Part A: Global and Sectoral Aspects: Contribution of Working Group II to the Fifth Assessment Report af the International Panel on Climate Change.

Kloos H. (1982). - Development, drought and famine in the Awash Valley of Ethiopia. Afr. Stud. Rev., 21-48.

Lane, C. (1998). 'Introduction', in C. Lane (ed.), Custodians of the Commons: Pastoral Land tenure in East and West Africa, London: Earthscan Publishers Ltd. 125.

Lind, J., Sabates-Wheeler, R. \& Kohnstamm, S. (2016). Changes in the drylands of Eastern Africa: implications for resilience-strengthening efforts. Brighton: Institute of Development Studies. Retrieved from:

Lind, J., Sabates-Wheeler, R. \& Kohnstamm, S. (2016). Changes in the drylands of Eastern Africa: implications for resilience-strengthening efforts. Brighton: Institute of Development Studies. Retrieved from: https://opendocs.ids.ac.uk/opendocs/handle/123456789/1208 
Mahli Ismail (2019). The Problem of Property Rights to Land Acquisition of State (Jurisprudence and Conditions in Land National Law). Udapest International Research and Critics Institute Journal. 68-77.

Melville, E.K.G. (1994). A plague of sheep: environmental consequences of the conquest of Mexico. Cambridge: Cambridge University Press.

Mohammed Yimer (2015). Pastoral Development Pathways in Ethiopia; the Policy Environment and Critical Constraints. Brief for GSDR 2015, Arba Minch University.

Nori, S. and M. Gemini. (2011). The Common Agricultural Policy vis-à-vis European pastoralists: Principles and practices. Pastoralism: Research, Policy and Practice.

Pastoralist Knowledge Hub: http://www.fao.org/ pastoralist-knowledge-hub/background/en/ (accessed on November 2016).

Peter D. Little, John McPeak, Christopher B. Barrett and Patti Kristjanson, (2008). Challenging Orthodoxies: Understanding Poverty in Pastoral Areas of East Africa. Development and Change 587-611.

Rettberg S. (2010). - Contested narratives of pastoral vulnerability and risk in Ethiopia's Afar Region. Pastoralism: Res., Pol., Pract.,248-273.

Rettberg, S., Beckmann, G., Minah, M. \& Schelchen, A. (2017). Ethiopia's arid and semi-arid lowlands: towards inclusive and sustainable rural transformation. SLE Discussion Paper 03/2017. Berlin: Centre for Rural Development (SLE). Retrieved from: https://edoc.huberlin.de/bitstream/handle/18452/18671/03.pdf?sequence=1

Robinson, T.P., P.K. Thornton, G.Franceschini, R.L. Kruska, F.Chiozza, A.Notenbaert, G.Cecchi, M. Herrero, M. Epprecht, S. Fritz, L. You, G. Conchedda, and L. See. 2011. Global livestock production systems. Food and Agriculture Organization of the United Nations and International Livestock Research Institute, Rome

Roger Blench (2001). 'You can't go home again' Pastoralism in the new millennium. Overseas Development Institute. http://www.org.odi.uk/staff/r.blench

Sara Pantuliano and Mike Wekesa (2008). Improving Drought Response in Pastoral Areas of Ethiopia: The case of Somali and Afar regions and Borana zone of Oromia region. Humanitarian Policy Group Overseas Development Institute, London.

Stark J. et al., (2011). Climate Change and Conflict in Pastoralist Regions of Ethiopia: Mounting Challenges, Emerging Responses. U.S. Agency for International Development. www.usaid.gov

Sue Lautze, Yacob Aklilu, Angela Raven-roberts, Helen Young, Girma Kebede, Jennifer Leaning., (2003). Risk and Vulnerability in Ethiopia: Learning from The Past, Responding to The Present, Preparing for The Future. A Report for The U.S. Agency For International Development.

Suheri, Kholil, S. and Lubis, L. (2019). The Communication Patterns of Single Parent Families in Forming Children's Morals in Medan City. Udapest International Research and Critics Institute Journal. 134-143.

Swallow, (1994) cited in Holden et al., Livestock and Poverty Interactions: A review of the literature. Livestock in Development Ltd 1997.

UNICEF (2014). Educations and Resilience in Kenya's Arid Lands. Nairobi, 2015.

United Nation Development Program (2010). Pastoralism in Ethiopia: its total economic values and development challenge. A knowledge management study implemented by Sos Sahel Ethiopia 